
O Centro Brasileiro de Análise e Planejamento e a revista Novos Estudos lamentam o falecimento do professor Juarez Brandão Lopes, a 9 de junho de 2011. Sociólogo, um dos fundadores do Cebrap e membro do conselho editorial desta revista, Juarez teve sua carreira marcada pelo trabalho interdisciplinare pela atuação tanto na academia (como pesquisador e professor na Universidade de São Paulo e na Fundação Getúlio Vargas) quanto na gestão pública (como diretordo Conselho Nacional de Desenvolvimento Científico e TecnológicoCNPq evice-presidente do Instituto de Pesquisa Econômica e Aplicada - Ipea, entre outros cargos do governofederal).

Em 1996, recebeu da presidência da República o título de comendador da Ordem Nacional do Mérito Científico e, em 2001, a Grã-Cruz. Recebeu ainda do Ministério das Relações Exteriores a comenda da Ordem do Rio Branco (2001) e, no mesmo ano, a Medalha Capes 50 anos, outorgada pelo Ministério da Educação.

\section{AMIGO JUAREZ}

\section{ELZA BERQUÓ}

Minha convivência com Juarez começou durante o período que precedeu à criação do Cebrap.

A despeito das sérias restrições impostas pelo regime militar, Juarez corajosamente abriu sua casa na Aclimação para que o grupo que se tornaria fundador pudesse planejar e construir o projeto que daria vida à nova instituição.

Uma vez no Cebrap, tive a oportunidade de contar com sua inestimável colaboração nas discussões teóricas e no delineamento da Pesquisa Nacional sobre Reprodução Humana, marco de mudança de paradigmas nas pesquisas demográficas realizadas até então.

Embora grandeestudioso da Sociologia Industrial e Urbana, nesse

[1] Lopes, Juarez Rubens Brandão. Tipos de áreas rurais do Brasil. São Paulo: Cebrap, 1975 (mimeo)
[2] Entrevista sobre os 40 anos do Cebrap. In: Montero, Paula e Moura, Flávio (orgs.) Retrato de Grupo-40Anos do Cebrap. São Paulo: Cosac Naify, 2009, pp.328: 119 . período, Juarez dedicava-se aos estudos agrários e construiu para a Pesquisa uma tipologia de áreas rurais no Brasil' ${ }^{1}$, baseada nas formas dominantes de organização da produção e de inserção de cada região na divisão social do trabalho durante o processo de desenvolvimento.

Nos anos que se seguiram fomos colegas e amigos até a madrugada de 9 de junho, quando ele nos deixou.

Juarez deixa um sólido legado de contribuições na área das Ciências Sociais - com importantes repercussões no campo dos estudos populacionais -, marcado pela criatividade e comprometimento com a geração e aplicação de conhecimentos científicos humanizados.

Em depoimento na comemoração dos 40 anos do Cebrap, Juarez disse: "Lembro, quando comecei a ter contato com a sociologia das políticas públicas, que eu pensava nesse papel do Cebrap de interferir com o seu conhecimento na germinação de novas políticas ou para que elas fossem mais bem-sucedidas" ${ }^{2}$. 